УДК 58(234.851 - 924.81)

doi: $10.31140 / j . v e s t n i k i b .2020 .1(212) .4$

\title{
РАЗНООБРАЗИЕ ГОРНЫХ ТУНДР С ПРЕОБЛАДАНИЕМ В НАПОЧВЕННОМ ПОКРОВЕ ЛИШАЙНИКОВ В ПРЕДЕЛАХ ЗАПАДНОГО МАКРОСКЛОНА ПРИПОЛЯРНОГО И СЕВЕРНОГО УРАЛА
}

\author{
Е.Е. Кулюгина, Ю.А. Дубровский \\ Институт биологии Коми научного центра Уральского отделения Российской академии наук, Сыктывкар \\ E-mail: kulugina@ib.komisc.ru
}

\begin{abstract}
Аннотация. В статье приведены данные о разнообразии сообществ горных тундр с преобладанием в напочвенном покрове лишайников ключевых участков Приполярного (хребты Малдынырд, Юаснырд, горы Баркова, Еркусей) и Северного (горный массив Тэлпозиз) Урала. Дана характеристика их структуры, видовой насыщенности, приведены списки доминирующего комплекса видов. Проведена NMS-ординация сообществ, позволившая выделить группы описаний, соответствующие синтаксонам, и показавшая высокую степень зависимости распределения выделенных групп от высоты расположения сообществ. Выявлено 12 синтаксонов лишайниковых тундр ранга ассоциации.
\end{abstract}

Ключевые слова: лишайниковые тундры, разнообразие и ординация сообществ, Приполярный и Северный Урал

\section{Введение}

Тундровые сообщества с преобладанием в напочвенном покрове лишайников тяготеют к наиболее высоким участкам горного рельефа, располагаясь в верхней части горно-тундрового пояса и гольцах Приполярного и Северного Урала с наиболее суровыми условиями существования. Для почв свойствены кислая реакция среды, низкое содержание питательных элементов, относительно высокая температура на поверхности и глубине 10 см по сравнению с другими группами сообществ (Новаковская, 2019). Сообщества лишайниковой тундры северных секторов Урала достаточно разнообразны. Выделяют несколько групп ассоциаций по преобладанию тех или иных видов лишайников в напочвенном покрове: алекториевые (с доминированием Alectoria ochroleuca), цетрариевые (с высоким обилием Flavocetraria nivalis), кладониевые (с преобладанием видов рода Cladonia) (Юдин, 1954; Растительный покров ..., 2006; Биоразнообразие ..., 2010). К их общим характеристикам относятся каменистость субстрата, разреженность верхнего (травяного, травяно-кустарничкового или кустарничкового) яруса и господство лишайников в напочвенном покрове.

Растительный покров национального парка «Югыд ва" лучше изучен в его северной части (Юдин, 1954; Лащенкова, 1977; Непомилуева, 1978, 1986; Мартыненко, 1986, 2001, 2003; Лавренко, 1994; Дёгтева, 2000; Куваев, 2006; Биоразнообразие ..., 2010; Сравнительный анализ ..., 2014; Высотная дифференциация ..., 2015; Флора и редкие ..., 2015; Флора ..., 2016; Флоры ..., 2016; Кулюгина, 2018). Растительность южной части парка остается малоисследованной. Первое обследование растительного покрова в междуречье Подчерья и Щугора было проведено в 1940-е гг. Ю.П. Юдиным (1950).

В 2016-2018 гг. сотрудниками Института биологии проведены ботанические исследования в южной части парка на массиве Тэлпозиз (Изменения предгорных ..., 2016; Редкие растения ..., 2017; Экотопическая приуроченность ..., 2017; Хвойные леса ..., 2019). Эти работы в основном посвящены изучению флоры сосудистых растений и разнообразия лесных сообществ.

Цель настоящей статьи - обобщить полученные геоботанические материалы о растительности лишайниковых тундр на изученных ключевых участках Приполярного и Северного Урала и выявить их синтаксономическое разнообразие.

\section{Материалы и методы}

Исследования выполнены на ключевых участках, расположенных на территории национального парка «Югыд ва» в его северной части - на Приполярном Урале (хребты Малдынырд, Юаснырд, горы Баркова, Еркусей) в 2005, 2009, 2012, 2014,2015 гг. и в южной части - на Северном Урале в пределах горного массива Тэлпозиз и окрестностях горы Пеленёр. В 2016 г. исследования проводили на хребте Тэлпозиз в окрестностях горы Хальмерсале (правый приток р. Хальмерья в бассейне р. Щугор) и на горе Пеленёр, в 2017 г. - в верховьях р. Тэлпозью, в 2018 г. в верховьях р. Тэлпоз (рис. 1).

В растительном покрове обследованной территории отчетливо выделяются несколько высотных поясов растительности: горно-лесной, подгольцовый, горно-тундровый и гольцовый. Они постепенно сменяют друг друга при продвижении вверх по высотному градиенту. Верхняя граница леса находится на высотах от 210-680 (Приполярный Урал) до 550-650 м над ур.м. (Северный Урал). Выше расположен горно-тундровый пояс, сменяющийся на обоих отрезках Урала с уровня 800-1000 м гольцовым поясом (Куваев, 2006; Высотная дифференциация ..., 2015; Хвойные леса ..., 2019).

Для изучения растительности применяли метод закладки пробных площадей при маршрут- 
ном обследовании территории с учетом данных космоснимков Lansat. При выборе и описании пробных площадей использованы общепринятые геоботанические методы (Антропогенная динамика ..., 1995). Для выявления разнообразия сообществ данной территории пробные площади закладывали в центре растительного контура. Описания выполняли на площадках размером $25 \mathrm{~m}^{2}$ или в рамках естественных границ контуров фитоценозов. На Приполярном Урале сделано 50 описаний лишайниковых тундр, на Северном 91 описание (рис. 1). Их координатную привязку выполняли с использованием GPS-навигатоpa. На каждой площадке учитывали видовой состав и структуру сообщества. Названия видов сосудистых растений приведены по базе данных www.plantarium.ru, лишайников - по R. Santesson (2004), мхов - по сводке М.С. Игнатова и O.M. Афониной (2006). Обработка описаний растительности сделана в программе Excel в соответствии с подходами школы Браун-Бланке (Миркин, 2001) на основе коэффициента СъеренсенаЧекановского с учетом проективного покрытия видов. Описания, близкие по составу и соотношению видов в сообществе, при значении коэффициента Съеренсена-Чекановского, близкого к 50 \% объединяли в один тип сообществ. Для ординации сообществ использовали алгоритм NMS-opдинации анализа данных, реализованный в модуле ExStaR (Новаковский, 2016).

\section{Результаты и обсуждение}

Гольцовый пояс. Ландшафтный облик гольцового пояса на Приполярном Урале определяют каменистые пустоши, перемежающиеся с участками горно-тундровых сообществ: в увлажненных экотопах - осоково-моховых (с доминированием Carex arctisibirica), осоково-ивково-моховых, а в местах с хорошим дренажом - травяно-лишайниковых, кустарничково-лишайниковых и лишайниковых каменистых горных тундр, а также нивальных луговин. На обследованных участках Северного Урала лишайниковые тундры являются основным типом растительности гольцового пояса, занимают большие площади. Кроме них здесь встречаются осоково-мохово-лишайниковые тундровые сообщества и ивково-травяно-моховые луговины, а в экотопах с рекреационным или зоогенным влиянием - злаковые фитоценозы.

Осоково-лишайниковые сообщества (тип сообществ Carex arctisibirica-Cladonia stellaris) приурочены к высотам 1243-1351 м над ур.м. на нагорном плато горы Баркова (Приполярный Урал), где отмечены наиболее суровые условия существования растений. Видовая насыщенность составляет 25-40 таксонов на пробную площадь. Общее проективное покрытие (ОПП) - 80-98 \% . Растения находятся в одном слое высотой до $15 \mathrm{~cm}$, в котором по покрытию преобладают травы (5-

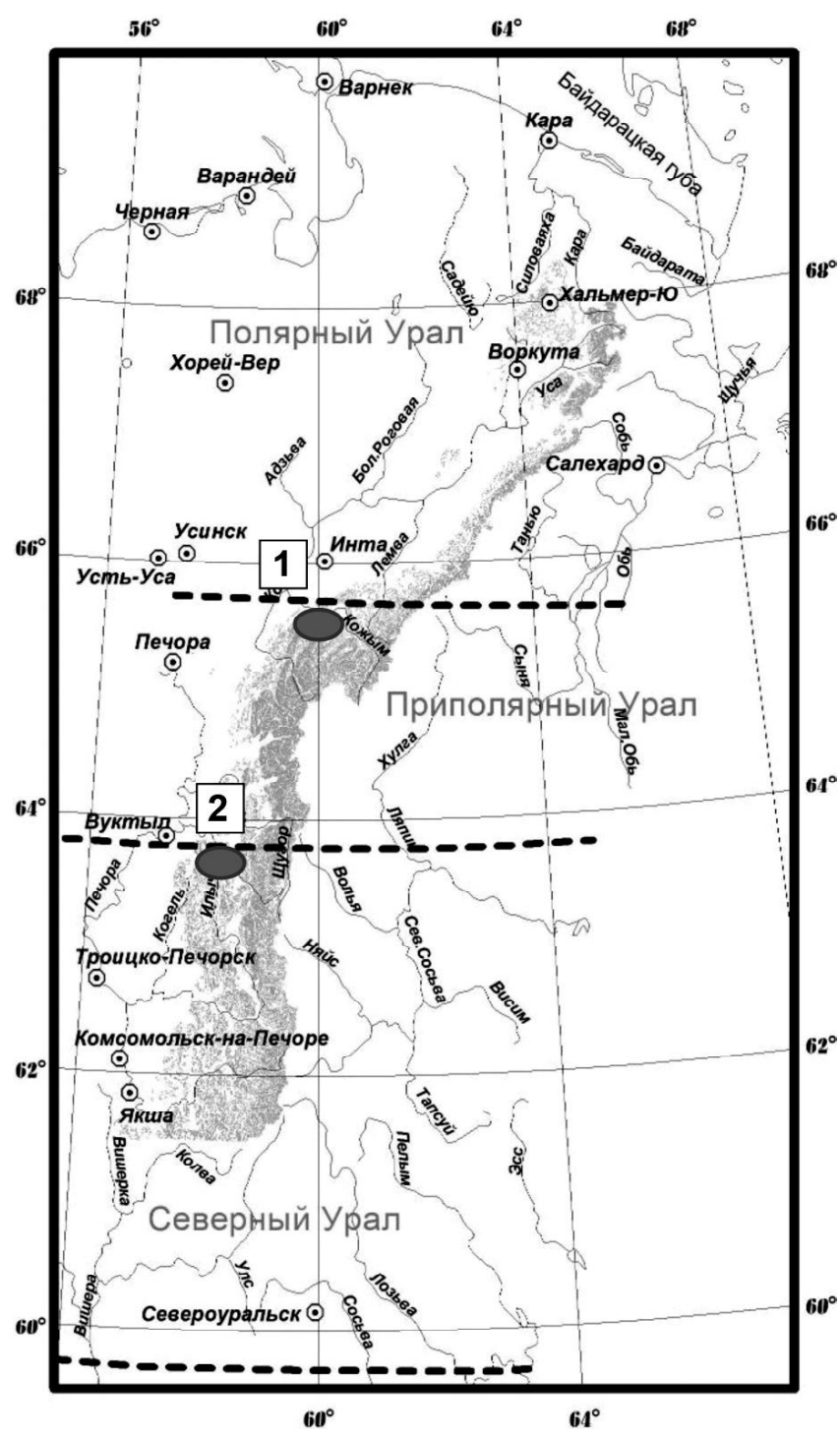

Рис. 1. Карта-схема ключевых участков района исследований: 1 - Приполярный Урал (хребты Малдынырд, Юаснырд, горы Баркова, Еркусей), 2 - Северный Урал (хребет Тэлпозиз, гора Пеленёр).

$40 \%$ ) и лишайники (70-95\%). Доминирующий комплекс состоит из видов сосудистых растений Carex arctisibirica, мхов - Racomitrium lanuginosum и лишайников: Cladonia arbuscula, Flavocetraria nivalis. Содоминантами выступают лишайники: Alectoria ochroleuca, Cladonia rangiferina, C. stellaris, C. stygia, C. uncialis и мхи рода Polytrichum.

Травяно-лишайниковые сообщества (тип сообществ Carex arctisibirica-Novosieversia glacialis-Alectoria ochroleuca) расположены на верхней нагорной террасе горы Баркова (Приполярный Урал) и на прилегающих к ней склонах южной, северной, западной и юго-западной экспозиции на высотах 1272-1336 м над ур.м. Видовая насыщенность составляет 41-60 таксонов. ОПП исследуемых фитоценозов - 50-98 \% . В сообществах можно выделить два яруса: травяной высотой 10-15 см и напочвенный - высотой до 5 см, сформированный преимущественно лишай- 
никами. Горизонтальная структура представляет собой куртины, образованные Novosieversia glacialis в сочетании с Carex arctisibirica и другими видами растений, лишайниками, перемежающиеся с каменистыми участками, которые могут быть округлой или вытянутой формы. Кроме вышеназванных видов, наибольшее обилие в напочвенном покрове здесь имеют Cladonia mitis, Alectoria ochroleuca, Flavocetraria nivalis. Этот тип сообществ отличается от близких к ним фитоценозов с доминированием Novosieversia glacialis, известных из смежных регионов (Матвеева, 2006; Растительные покров ..., 2006; Телятников, 2010; Кулюгина, 2018).

Осоково-мохово-лишайниковые сообщества (тип сообществ Carex arctisibirica-Cetraria islandica) расположены на высотах 837-1178 м над ур.м. на нагорных плато и в верхних частях горных склонов. Видовая насыщенность составляет 13-35 таксонов на пробную площадь. Камни и пятна пучения, как правило, занимают до 40 \% площади. ОПП сообществ - 60-95 \% . Вертикальная структура включает два яруса: разреженный травяно-кустарничковый высотой до 30 см и хорошо выраженный мохово-лишайниковый высотой до 10 см. В первом обильны травы: Carex arctisibirica (доминант), Bistorta officinalis, Artemisia norvegica, Anemonastrum biarmiense, Lagotis uralensis, Festuca ovina, во втором - лишайники Cetraria islandica, Cladonia arbuscula, C. rangiferina, Flavocetraria nivalis, Stereocaulon paschale и мхи родов Polytrichum и Dicranum. Сообщества выявлены на Северном Урале в окрестностях гор Хальмерсале, Пеленёр, Тэлпозиз.

Осоково-лишайниковые фитоценозы (тип сообществ Carex arctisibirica-Flavocetraria nivalis) распространены в гольцовом поясе на высотах 906-1240 м над ур.м., где занимают сухие участки нагорных плато и прилегающие к ним верхние части склонов. ОПП составляет 95-100\%, видовая насыщенность - 14-31 таксонов. Высота растений здесь минимальная - 5-10 см. Кустарнички растут разреженно, возвышаясь над плотным лишайниковым ковром. Наиболее обильные виды образуют доминантный комплекс, в который входят сосудистые растения Carex arctisibirica, Salix numullaria, лишайники Flavocetraria nivalis, Cladonia rangiferina, Cetraria islandica, Cladonia arbuscula, Alectoria ochroleuca и мхи Racomitrum lanuginosum, Polytrichum commune, P. strictum. Сообщества встречаются на Северном Урале в окрестностях горы Хальмерсале и верховьях р. Тэлпоз.

Выделенные (травяно-)осоково-лишайниковые сообщества гольцового пояса сходны с описанными Ю.П. Юдиным (1954), который отмечал, что эти фитоценозы с продвижением на север от хребта Тэлпозиз встречаются чаще и занимают все большие площади на плоских платообразных вершинах гор, перевалах, пологих склонах на маломощных щебневатых влажных суглинках со следами оглеения. Эти тундры образуются в крайне жестких для высших растений условиях, что приводит к упрощению ярусности сообществ (они приближаются к одноярусным), подавлению развития цветковых растений, а облик и структуру сообществ определяют преимущественно лишайники (Юдин, 1954).

Вопрос о принадлежности осоково- и травянолишайниковых сообществ к высшим синтаксономическим единицам пока остается открытым. С одной стороны, мы не можем отнести их к классу зональной растительности Carici arctisibiricaeHylocomietea alaskani Matveyeva et Lavrinenko 2016, поскольку этот класс объединяет растительность водоразделов со средним накоплением снега и мощным моховым покровом (Лавриненко, $2016,2018)$, а изученные нами фитоценозы существуют в условиях гольцового пояса и в их напочвенном покрове преобладают лишайники. С другой стороны, в обследованных нами сообществах из диагностических видов этого класса доминирует Carex arctisibirica и активно проявляет себя Racomitrium lanuginosum, имеющий высокие показатели постоянства и обилия. Другие диагностические виды класса Carici arctisibiricae-Hylocomietea alaskani Matveyeva et Lavrinenko 2016 (Bistorta vivipara, Lagotis minor, Poa arctica, Valeriana capitata, Hylocomium splendens, Aulacomnium turgidum, Ptilidium ciliare, Salix polaris) встречаются здесь редко и с низким обилием. Для более четкого позиционирования описанных синтаксонов в системе классификации тундровой растительности необходимы дальнейшие исследования.

Кустарничково-лишайниковые тундры с преобладанием Alectoria ochroleuca (тип сообществ Empetrum hermaphroditum-Arctagrostis latifolia-Alectoria ochroleuca) размещаются на высотах 800-1020 м над ур.м. на плато горы Баркова (Приполярный Урал) и ее склонах. Фитоценозы насчитывают 26-42 вида на пробную площадь. ОПП - 80-98 \% . Высота растений - до 15 (20) см. По покрытию преобладают кустарнички (5-50 \%) и лишайники (50-100 \% ) при минимальном участии трав и мхов. Доминанты сообществ из лишайников: Alectoria ochroleuca, Flavocetraria nivalis, Cladonia arbuscula, из сосудистых растений: Betula nana, Empetrum hermaphroditum.

Пятнистые кустарничково-алекториевые фитоценозы (тип сообществ Arctous alpina-Alectoria ochroleuca) встречены на нагорных плато на высотах 714-957 м над ур.м. Для них характерны пятна пучения, занимающие вместе с камнями до 25 \% поверхности. ОПП варьирует от 75 до $80 \%$. Видовая насыщенность сообществ составляет 22-41 таксон. Все растения находятся примерно в одном слое с максимальной высо- 
той до 20-30 см при высоте лишайникового яруса до 12 см. Наибольшее покрытие в фитоценозах у кустарничков (30-40 \% ) и лишайников (75$80 \%)$. Доминирующий комплекс включает следующие виды сосудистых растений: Salix nummularia, Arctous alpina, Betula nana, Empetrum hermaphroditum, Vaccinium uliginosum и лишайников: Alectoria ochroleuca, Cladonia arbuscula, C. rangiferina, Flavocetraria nivalis. Сообщества описаны на Северном Урале в окрестностях горы Пеленёр и верховьях р. Тэлпоз.

Горно-тундровый пояс. Растительность горнотундрового пояса на Приполярном Урале представлена кустарничковыми (травяно-моховыми, мохово-лишайниковыми, лишайниковыми), ерниковыми (травяно-моховыми, лишайниково-моховыми) тундрами, кроме них отмечены ивняки разнотравные, осоково-моховые и разнотравнозлаковые сообщества (Биоразнообразие ..., 2010). Наибольшие площади горных склонов на исследованной территории Северного Урала заняты кустарничковыми тундрами, состав и структура которых изменяются в зависимости от положения в рельефе и степени увлажненности субстрата. На повышенных элементах рельефа расположены сообщества с преобладанием в напочвенном покрове лишайников. Как правило, в этих экотопах формируются пятна пучения, обрамленные камнями, они занимают до 50 \% поверхности почвы. На горных склонах, где условия увлажнения благоприятнее, формируются сомкнутые фитоценозы с доминированием мхов.

Пятнистые кустарничково-лишайниковые тундры с преобладанием лишайников рода Cladonia (тип сообществ Empetrum hermaphroditumVaccinium vitis-idaea-Cladonia arbuscula) расположены на выположенных верхних частях горных склонов и нагорных террас на высотах 700850 м над ур.м. Пятна пучения могут занимать до $50 \%$ поверхности. Видовая насыщенность сообществ - 24-45 таксонов. ОПП - 50-100\%. Сообщества двухъярусные: верхний - травянокустарничковый, разреженный, высотой до 20 см; напочвенный покров (до 5 см) сложен преимущественно лишайниками. Доминантный комплекс синтаксона включает лишайники Flavocetraria nivalis, Cladonia arbuscula, C. rangiferina, C. stygia и сосудистые растения: Ledum decumbens, Betula nana, Empetrum hermaphroditum, Vaccinium uliginosum. Сообщества описаны на хребтах Юаснырд, Малдынырд и горе Баркова (Приполярный Урал). Данные сообщества близки к фитоценозам ассоциации Cladonio stellaris-Vaccinietum uliginosi Sinelnikova 2013, распространённой на пологих склонах хребта Черского (Магаданская область). Сообщества лишайниковых тундр с преобладанием кладоний распространены в гольцовом поясе всех горных систем северо-востока Азии (Синельникова, 2013).
Пятнистые кустарничково-лишайниковые сообщества с преобладанием Arctous alpina (тип сообществ Empetrum hermaphroditum-Arctous alpina-Stereocaulon paschale) встречаются на высотах 605-950 м над ур.м. на горных склонах, террасах, плато, в верхних частях горного рельефа, где занимают небольшие участки между курумами. Камни и пятна на поверхности грунта занимают до $20 \%$. ОПП сообществ варьирует в пределах 60-100\%. Наблюдается высокое видовое разнообразие - 31-67 таксонов на пробную площадь. Высота растений составляет 10-15 см, при этом напочвенный слой, состоящий из лишайников, минимален по высоте - 1-2 см. Фитоценозы сложены преимущественно кустарничками и лишайниками. Наибольшее обилие здесь у сосудистых растений: Ledum decumbens, Betula nana, Empetrum hermaphroditum и лишайников: Flavocetraria nivalis, Arctous alpina, Cladonia arbuscula, Stereocaulon paschale. Сообщества выявлены на Приполярном Урале в окрестностях оз. Большое Балбанты, на хребтах Малдынырд, Юаснырд, горе Баркова.

Пятнистые кустарничково-лохово-лищайниковые тундры (тип сообществ Salix nummularia-Racomitrium lanuginosum-Flavocetraria nivalis) очень часто встречаются в горно-тундровом поясе на высотах 603-877 м над ур.м. на нагорных плато, платообразных или пологих склоновых участках в местах с минимальным снежным покрытием, хорошо обдуваемых ветром. Здесь имеются пятна пучения, занимающие вместе с камнями до 50 \% поверхности. ОПП фитоценозов варьирует в пределах 40-95 \%, видовая насыщенность - 24-41 таксон на пробную площадь. Высота растений - 5-25 см. Кустарнички слегка возвышаются над мохово-лишайниковым покровом, высота которого 2-6 (10) см. Доминирующий комплекс состоит из сосудистых растений: Betula nana, Vaccinium uliginosum, Empetrum hermaphroditum, Arctous alpina, Salix numullaria, и лишайников: Flavocetraria nivalis, Cladonia arbuscula, Cetraria islandica, Cladonia rangiferina, Stereocaulon paschale. Сообщества отмечены на Северном Урале в окрестностях гор Хальмерсале и Пеленёр, в верховьях р. Тэлпоз.

Кустарничково-осоково-лишайниковые тундpы (тип сообществ Arctous alpina-Carex arctisibirica-Flavocetraria nivalis) приурочены к горным склонам и нагорным плато горно-тундрового пояса на высотах 655-900 м над ур.м. До $20 \%$ поверхности приходится на камни. Сообщества насчитывают 18-29 видов на пробную площадь. В них выделяются два яруса: травяно-кустарничковый высотой до $20 \mathrm{~cm}$ и мохово-лишайниковый высотой 5-10 см. Наиболее обильные виды сосудистых растений (Carex arctisibirica, Betula nana) и лишайников (Flavocetraria nivalis, Cetraria nigricans, C. ericetorum, Cladonia arbuscula) формируют доминантный комплекс. Фитоцено- 
зы описаны на Северном Урале в окрестностях горы Хальмерсале, в бассейне р. Тэлпоз-ю и в верховьях р. Тэлпоз.

Пятнистые дриадово-лишайниковые тундpы (тип сообществ Dryas octopetala-Cladonia arbuscula) приурочены к высотам 625-931 м над ур.м., где располагаются на нагорных плато, склонах в верхней части горно-тундрового пояса. Для них характерны пятна пучения, занимающие вместе с камнями до 50 \% поверхности. ОПП фитоценозов изменяется в пределах от 50 до $100 \%$, видовая насыщенность - 26-48 таксонов. Растительность низкорослая, в вертикальной структуре можно выделить два яруса: разреженный травяно-кустарничковый высотой до 20 см и напочвенный высотой 1-5 см. Наиболее обильные виды образуют верхний (Dryas octopetala, Vaccinium uliginosum, Arctous alpina, Betula nana) и нижний (Cladonia arbuscula, Cetraria islandica, Flavocetraria nivalis) ярусы. Сообщества зарегистрированы на Северном Урале в окрестностях гор Хальмерсале и Тэлпозиз, в верховьях р. Тэлпоз.

Филлодоце-чернично-цетрариевые тундры (тип сообществ Phyllodoce caerulea-Vaccinium myrtillus-Cetraria islandica) встречаются в горно-тундровом поясе небольшими контурами по горным склонам на высотах 577-821 м над ур.м. Сообщества на Северном Урале сомкнутые, на Приполярном Урале - до 20 \% поверхности на занимаемой ими площади приходится на камни. Фитоценозы двухъярусные, насчитывают 15-45 видов на пробную площадь на Приполярном Урале, 13-39 видов - на Северном Урале. Верхний ярус высотой до 20-30 см сформирован кустарничками (Vaccinium myrtillus, Phyllodoce caerulea, Vaccinium uliginosum, Empetrum hermaphroditum, Vaccinium vitis-idaea), нижний - высотой 1-3 см, сложен преимущественно лишайниками Cetraria islandica, Cladonia arbuscula, C. rangiferina, Stereocaulon paschale и мхами рода Dicranum.

Данные фитоценозы сходны с сообществами acсоциации Phyllodoco-Vaccinietum myrtilli Nord. 1943, описанной для Мурманской области (Королева, 2006) из союза Phyllodoco-Vaccinion Nordhagen 1943 - хионофитных кустарничковых и кустарниковых сообществ на хорошо дренированных почвах, умеренно увлажненных летом (Миркин, 2012). Сообщества встречаются как на Приполярном Урале на горах Баркова, Еркусей, хребте Малдынырд, так и на Северном Урале в окрестностях горы Хальмерсале и в бассейне р. Тэльпоз-ю.

Кустарничково-лишайниковые тундры гольцового и горно-тундрового поясов относятся к наиболее распространенным классам высокогорной растительности Евразии: Loiseleurio-Vaccinietea Eggler ex Schubert 1960 и Carici rupestris-Kobresietea bellardii Ohba 1974 (Миркин, 2012; Телятников, 2016). Большая часть выделенных ассо- циаций кустарничково-лишайниковых тундр относится к классу Loiseleurio-Vaccinietea Eggler ex Schubert 1960 - арктоальпийским кустарничковым сообществам на хорошо дренированных субстратах Евразии и Северной Америки. Тип сообществ Dryas octopetala-Cladonia arbuscula отнесен к другому классу - Carici rupestris-Kobresietea bellardii Ohba 1974 - тундрам на щебнистых карбонатных грунтах, где активно формируют растительный покров диагностические виды данного синтаксона.

В результате проведенной ординации описания сообществ лишайниковых тундр сгруппировались вдоль оси 1 (рис. 2, 3), которая показала высокую степень корреляции с вектором высоты над уровнем моря ( 0.83 для Приполярного Урала, r 0.62 для Северного Урала). Это подчеркивает отчетливое распределение сообществ исследуемого типа горных тундр по высотным поясам растительности - горно-тундровому и гольцовому. В результате ординации сообществ для гольцового пояса выявлено шесть типов сообществ ранга ассоциации. Для Приполярного Урала: $\boldsymbol{C a}$ rex arctisibirica-Cladonia stellaris; Carex arctisibirica-Novosieversia glacialis-Alectoria ochroleuca; Empetrum hermaphroditum-Arctagrostis latifolia-Alectoria ochroleuca. Для Северного Урала: Carex arctisibirica-Flavocetraria nivalis; Carex arctisibirica-Cetraria islandica; Arctous alpinaAlectoria ochroleuca. Для горно-тундрового пояса ординация показала наличие шести синтаксонов (рис. 2, 3): только на Приполярном Урале отмечены Empetrum hermaphroditum-Vaccinium vitis-idaea-Cladonia arbuscula; Empetrum hermaphroditum-Arctous alpina-Stereocaulon paschale; только на Северном - Salix nummulariaRacomitrium lanuginosum-Flavocetraria nivalis, Dryas octopetala-Cladonia arbuscula, Arctous alpina-Carex arctisibirica-Flavocetraria nivalis. Один тип сообществ - Phyllodoce caerulea-Vaccinium myrtillus-Cetraria islandica - характерен для горно-тундрового пояса обоих секторов Уральских гор.

Редкие виды лишайниковых тундр. В тундрах с доминированием в напочвенном покрове лишайников отмечено значительное число (35) редких и охраняемых в Республике Коми видов (см. таблицу; Красная книга ..., 2019). Один вид отнесен к категории статуса редкости 1 - находящийся под угрозой исчезновения, три - к категории статуса редкости 2 - сокращающиеся в численности. Большая часть редких видов (21), произрастающих в этих сообществах, имеет статус 3. Это виды с низкой численностью, распространенные на ограниченной территории. Для двух видов сведений о состоянии популяций недостаточно (категория 4). Среди редких есть эндемичные (Anemonastrum biarmiense, Papaver lapponicum subsp. jugoricum, Lagotis uralensis), реликтовые 


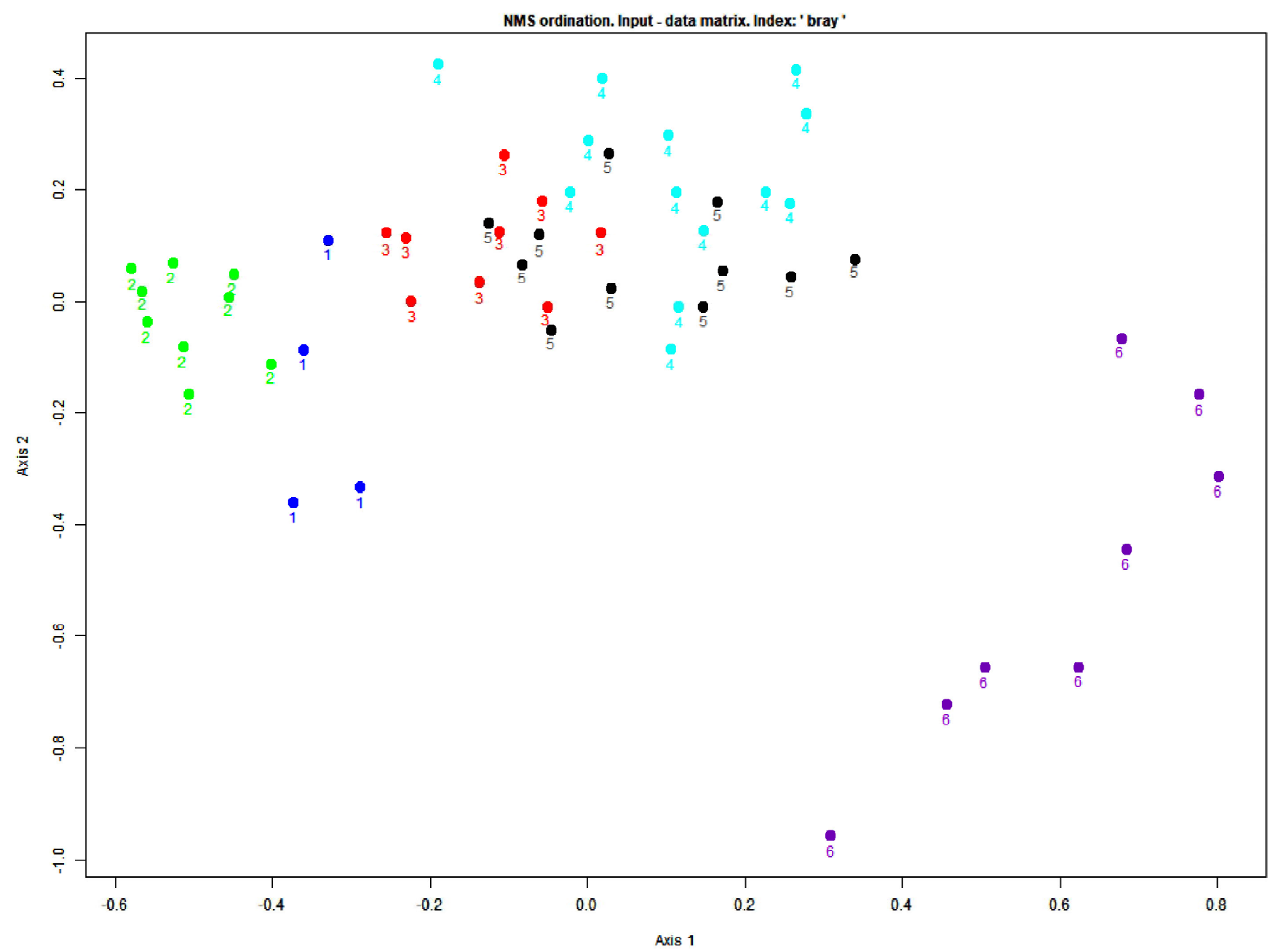

Рис. 2. NMS-ординация растительных сообществ лишайниковых тундр Приполярного Урала. Выделены группы сообществ гольцового (1 - осоково-лишайниковые сообщества Carex arctisibirica-Cladonia stellaris, 2 - травянолишайниковые Carex arctisibirica-Novosieversia glacialis-Alectoria ochroleuca, 3 - кустарничково лишайниковые с преобладанием алектории - Empetrum hermaphroditum-Arctagrostis latifolia-Alectoria ochroleuca) и горно-тундрового (4 - пятнистые кустарничково-лишайниковые с преобладанием лишайников рода Cladonia - Empetrum hermaphroditum-Vaccinium vitis-idaea-Cladonia arbuscula; 5 - пятнистые кустарничково-лишайниковые с преобладанием Arctous alpina - тип сообществ Empetrum hermaphroditum-Arctous alpina-Stereocaulon paschale; 6 кустарничково(филлодоце-чернично-)-цетрариевые сообщества - тип сообществ Phyllodoce caerulea-Vaccinium myrtillus-Cetraria islandica) поясов.

(Achoriphragma nudicaule, Oxygraphis glacialis, Artemisia norvegica, Rhodiola quadrifida, Potentilla kuznetzowii) растения и таксоны, популяции которых произрастают на границе ареалов (Crepis chrysantha, Draba alpina, Acomastylis glacialis, Polypodium vulgare, Pinus sibirica, Silene paucifolia, Tephroseris atropurpurea, Arctocetraria andrejevii, Cetraria laevigata). Один вид - Rhodiola rosea занесен в Красную книгу Российской Федерации (2008). Восемь видов нуждаются в особом контроле численности популяций и включены в список приложения (Красная книга ..., 2019) (см. таблицу). Наибольшее разнообразие редких видов зафиксировано в травяно-лишайниковых сообществах гольцового пояса (тип сообществ $\boldsymbol{C a}$ rex arctisibirica-Novosieversia glacialis-Alectoria ochroleuca) Приполярного Урала: 14 таксонов сосудистых растений и три - лишайников. Кро- ме них, здесь произрастают три таксона сосудистых растений и один вид мохообразных из приложения к Красной книге Республики Коми (см. таблицу; Кулюгина, 2018; Красная книга..., 2019).

Подавляющее большинство (29) редких растений и лишайников представлены группами арктической фракции, наибольшее разнообразие которых (23) зафиксировано на отрезке Приполярного Урала. К бореальной группе принадлежат всего пять таксонов, четыре из которых отмечены на Северном Урале (см. таблицу).

В сообществах лишайниковых тундр доминируют только два редких вида: Phyllodoce caerulea и Novosieversia glacialis. Большинство охраняемых таксонов произрастает в фитоценозах рассматриваемого типа с малым обилием и низкой встречаемостью, однако часть из них при малом обилии имеет достаточно высокое постоянство в сообществах (см. таблицу). 


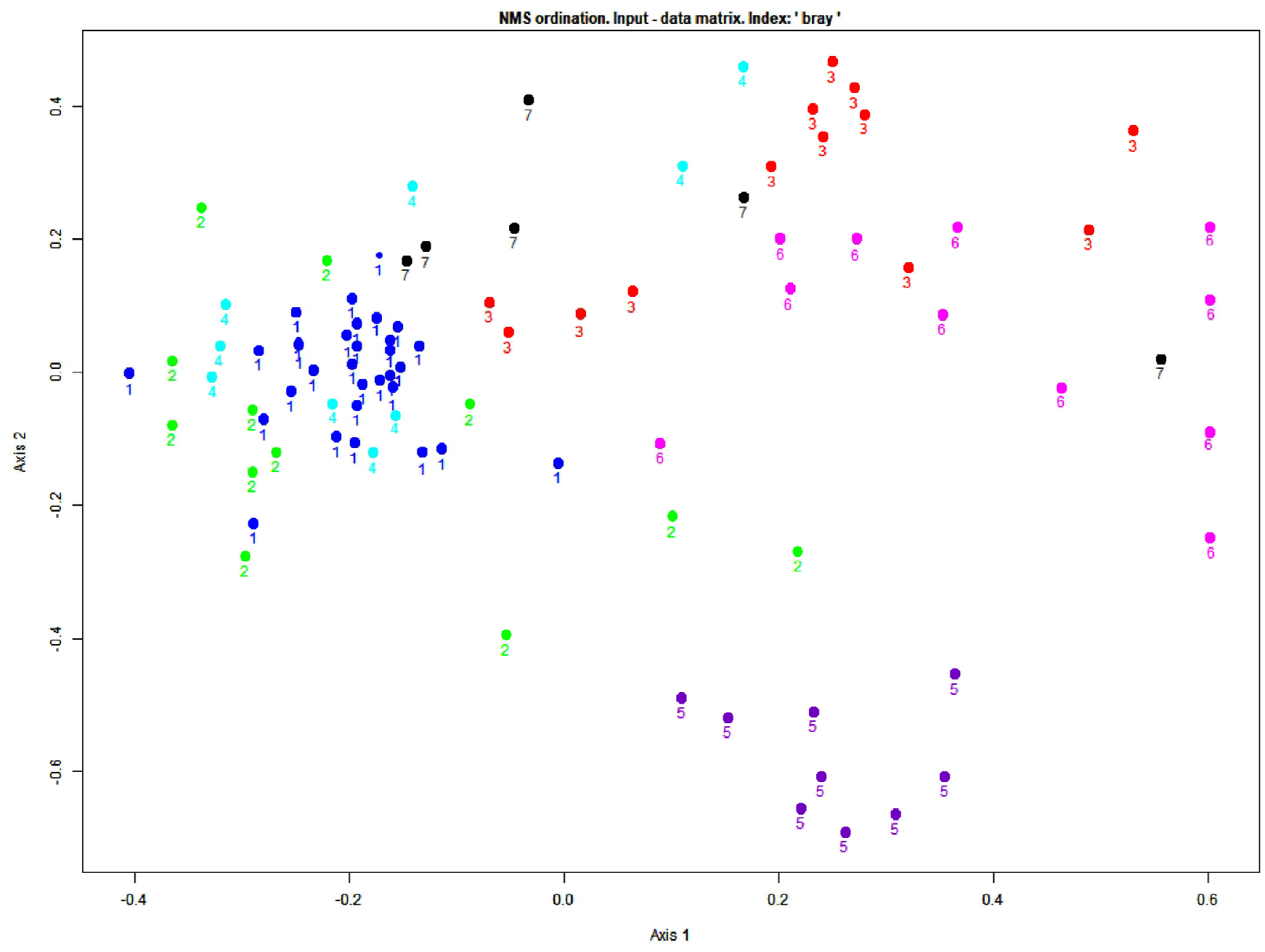

Рис. 3. NMS-ординация растительных сообществ кустарничково-лишайниковых тундр Северного Урала. Выделены группы сообществ гольцового (3 - осоково-лишайниковые сообщества - Carex arctisibirica-Flavocetraria nivalis, 6 - осоково-мохово-лишайниковые тундры - Carex arctisibirica-Cetraria islandica, 4 - пятнистые кустарничковоалекториевые фитоценозы - Arctous alpina-Alectoria ochroleuca) и горно-тундрового (1 - пятнистые кустарничково-мохово-лишайниковые сообщества - Salix nummularia-Racomitrium lanuginosum-Flavocetraria nivalis, 2 - пятнистые дриадово-лишайниковые тундры - Dryas octopetala-Cladonia arbuscula, 5 - кустарничково-(филлодоцечернично-)цетрариевые сообщества Phyllodoce caerulea-Vaccinium myrtillus-Cetraria islandica, 7 - кустарничково-осоково-лишайниковые сообщества - Arctous alpina-Carex arctisibirica-Flavocetraria nivalis) поясов.

В лишайниковых тундрах на Приполярном Урале отмечено 22 редких и охраняемых для Республики Коми видов сосудистых растений, три вида лишайников и один вид мохообразных, на Северном - 18 таксонов сосудистых растений и два вида лишайников (Красная книга ..., 2019; см. таблицу). Из них на обоих отрезках Уральских гор выявлено 11 видов, принадлежащих в подавляющем большинстве к арктической фракции. Среди них 10 таксонов сосудистых растений (Artemisia norvegica, Diapensia lapponica, Harrimanella hypnoides, Lloydia serotina, Loiseleuria procumbens, Phyllodoce caerulea, Rhodiola quadrifida, $R$. rosea, Xamilenis acaulis, Tephroseris atropurpurea) и один лишайник (Cetraria laevigata). Это свидетельствует о флористической ценности лишайниковых тундр Приполярного Урала как места произрастания редких видов Республики Коми.

\section{Заключение}

В Приполярном и Северном секторах западного макросклона Урала лишайниковые тундры расположены в горно-тундровом и гольцовом поясах. Их размещение в ландшафте зависит от высоты над уровнем моря и отражает спектр экологических условий. Ценотическое разнообразие лишайниковых тундр включает 12 синтаксонов ранга ассоциации. Приводим продромус, в котором высшие синтаксономические единицы даны по Миркину (2012), Лавриненко (2016) и Телятникову (2016):

Класс?

Порядок?

Союз?

Тип сообществ Carex arctisibirica-Cladonia stellaris

Тип сообществ Carex arctisibirica-Novosieversia glacialis-Alectoria ochroleuca 


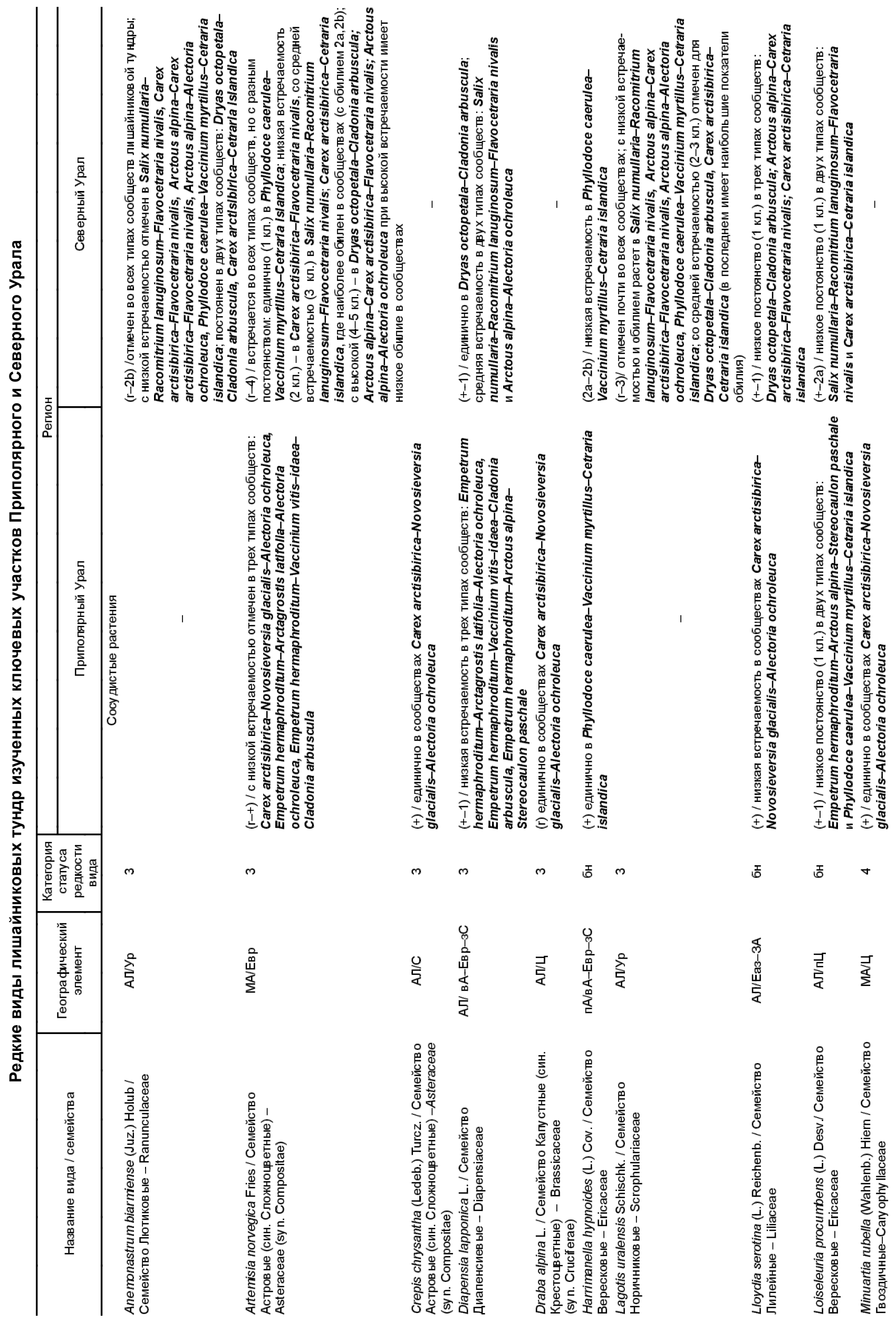




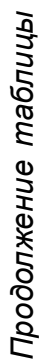

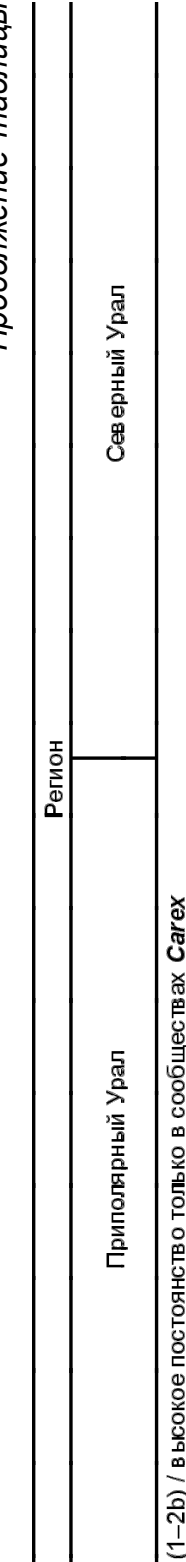

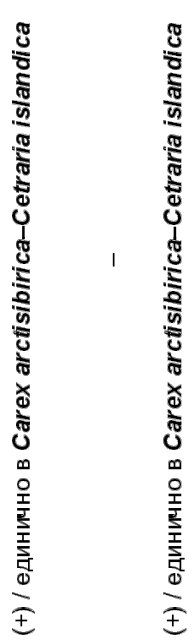

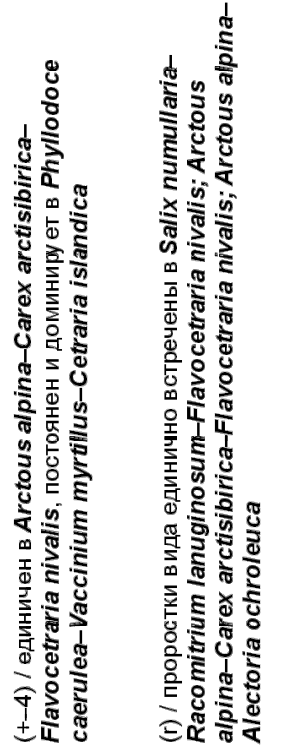

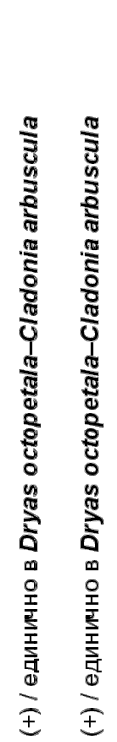

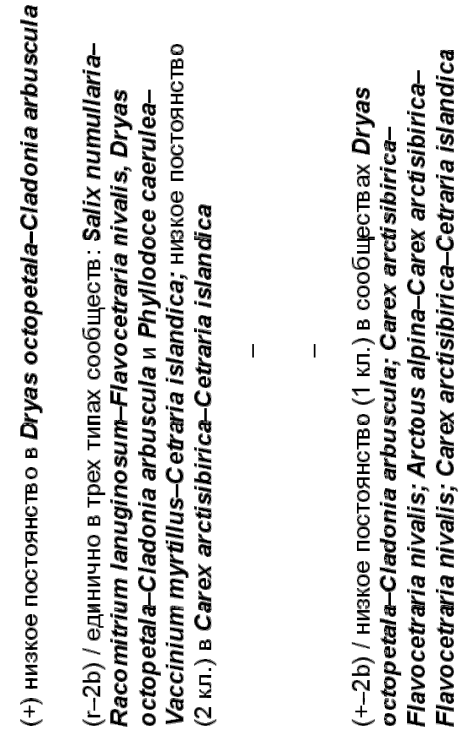

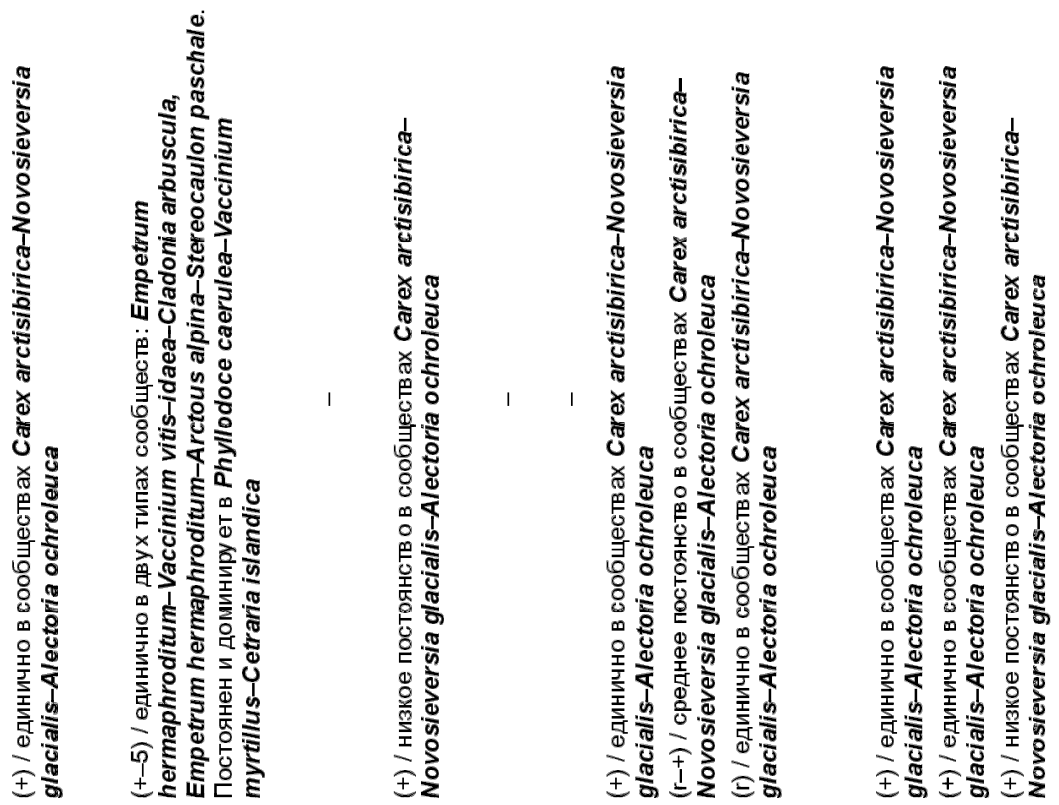

\begin{tabular}{|c|c|c|c|c|c|c|c|c|c|c|c|c|c|c|c|c|}
\hline 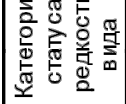 & $m$ & - & I & $N$ & m & $m$ & I & $N$ & $m$ & $m$ & m & $m$ & $N$ & $m$ & $m$ & I \\
\hline 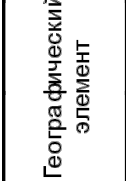 & $\mid \begin{array}{l}\mathbb{1} \\
0 \\
0 \\
0 \\
\frac{\alpha}{2} \\
\underline{\Sigma}\end{array}$ & 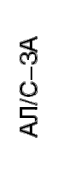 & 寻 & 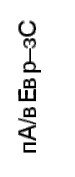 & 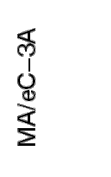 & 崇 & 丞 & 岀 & $\begin{array}{l}\frac{7}{\bar{E}} \\
\frac{\bar{x}}{2}\end{array}$ & 䞠 & $\begin{array}{l}\text { 总 } \\
\frac{1}{1} \\
\frac{1}{d} \\
\frac{1}{\Sigma}\end{array}$ & 灵 & 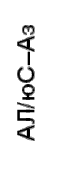 & 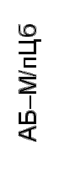 & $\begin{array}{l}\overrightarrow{\vec{E}} \\
\text { 豆 }\end{array}$ & 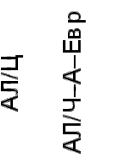 \\
\hline 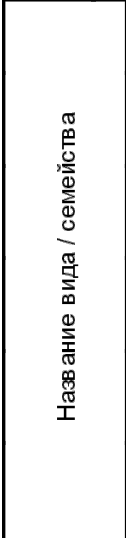 & 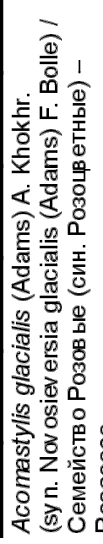 & 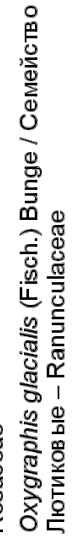 & 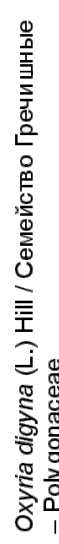 & 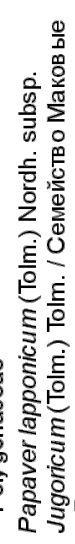 & 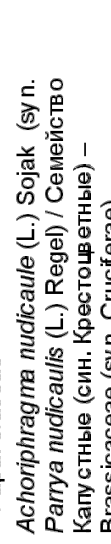 & 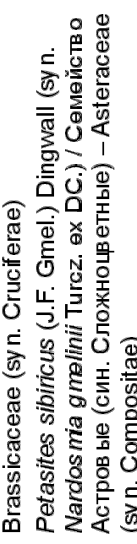 & 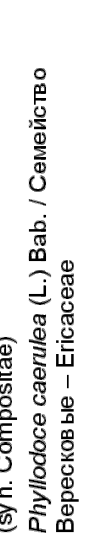 & 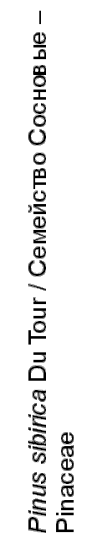 & 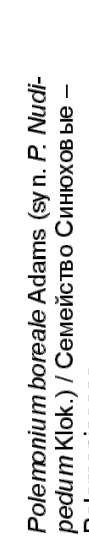 & 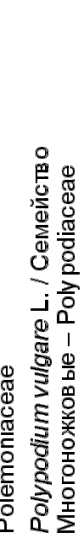 & 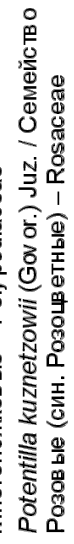 & 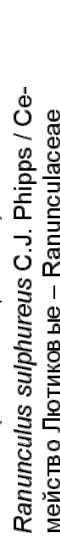 & 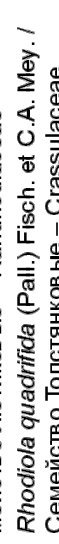 & 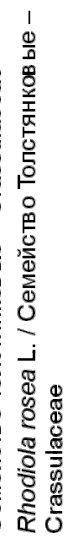 & 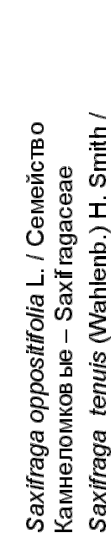 & 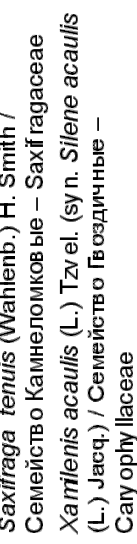 \\
\hline
\end{tabular}




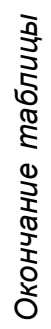
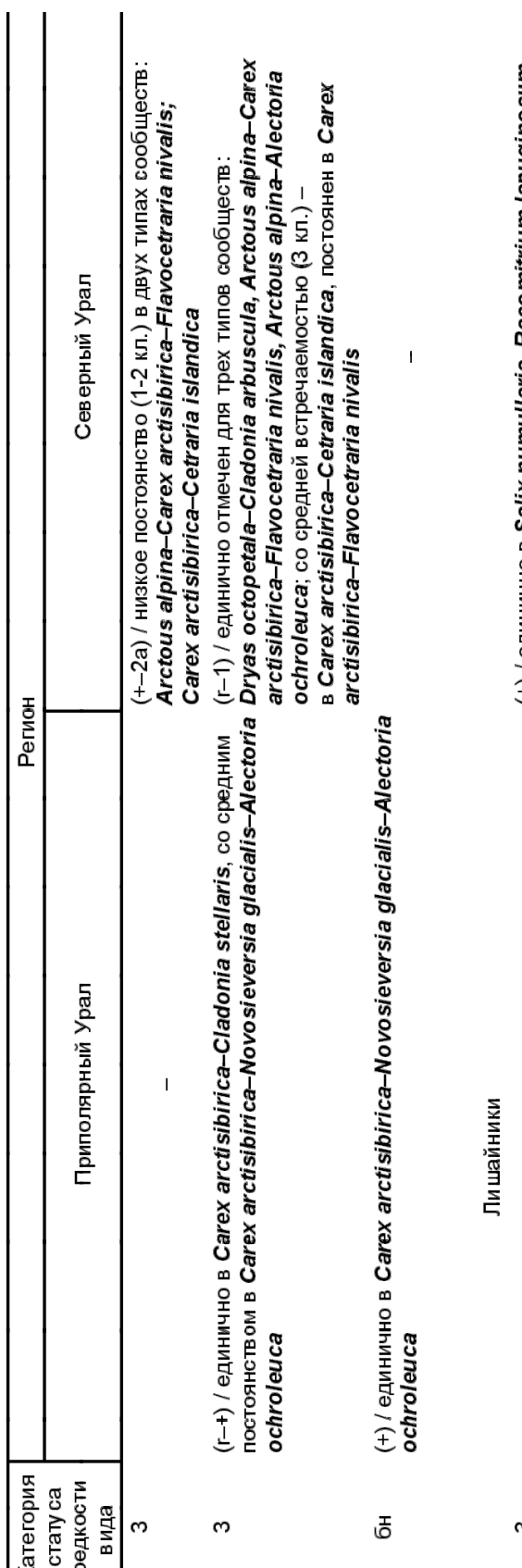
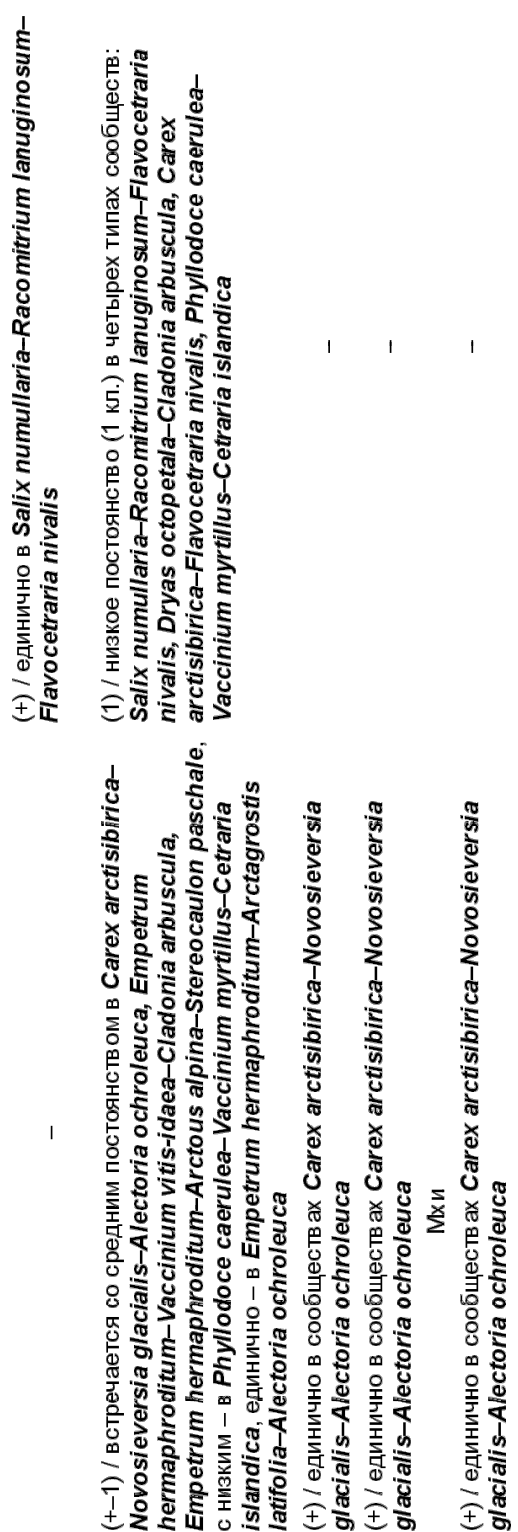

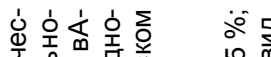

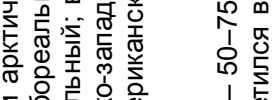

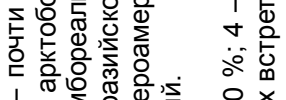

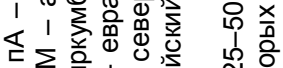

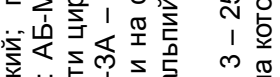

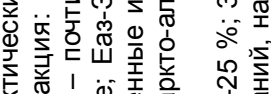

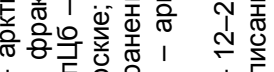

1 尔

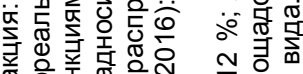

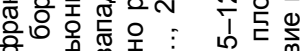

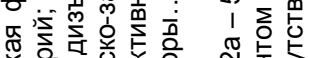

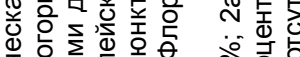

在

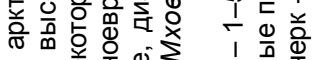

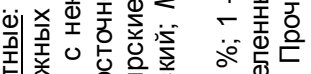

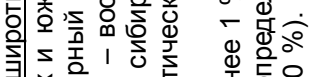

×保 1 형

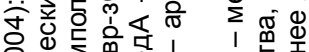

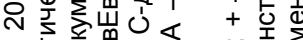

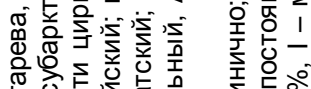

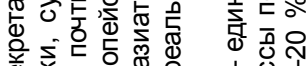

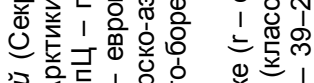

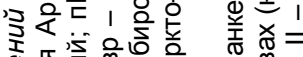

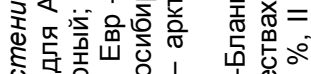

\&

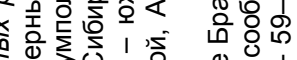

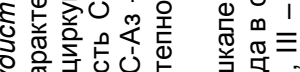

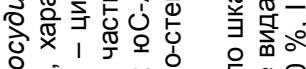

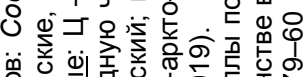

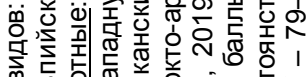

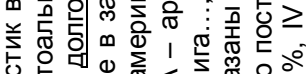

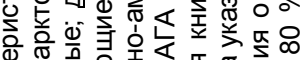

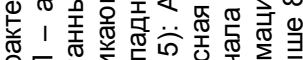

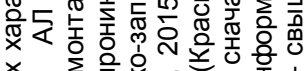

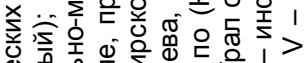

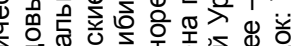

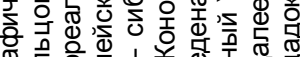
造

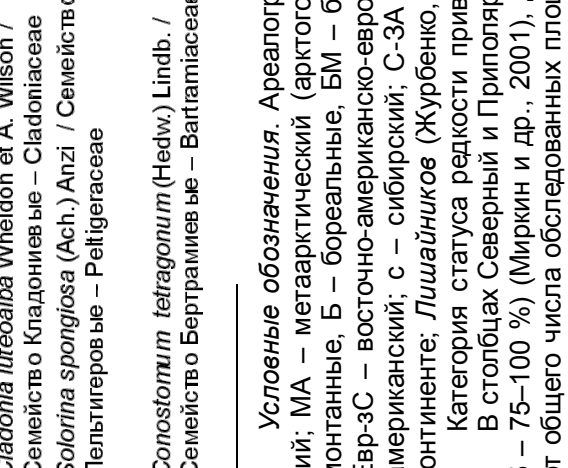


Тип сообществ Carex arctisibirica-Flavocetraria nivalis

Тип сообществ Carex arctisibirica-Cetraria islandica

Класс Loiseleurio-Vaccinietea Eggler ex Schubert 1960 Порядок Rhododendro-Vaccinietalia Br.-Bl. ex Daniels 1994

Союз Loiseleurio-Diapension (Br.-Bl., Sissingh et Vlieger 1939) Daniels 1982

Тип сообществ Arctous alpina-Alectoria ochroleuca

Тип сообществ Empetrum hermaphroditumArctagrostis latifolia-Alectoria ochroleuca

Тип сообществ Empetrum hermaphroditumVaccinium vitis-idaea-Cladonia arbuscula Тип сообществ Empetrum hermaphroditumArctous alpina-Stereocaulon paschale

Тип сообществ Arctous alpina-Carex arctisibirica-Flavocetraria nivalis

Тип сообществ Salix nummularia-Racomitrium lanuginosum-Flavocetraria nivalis

Союз Phyllodoco-Vaccinion myrtilli Nordh. 1943 Тип сообществ Phyllodoce caerulea-Vaccinium myrtillus-Cetraria islandica

Класс Carici rupestris-Kobresietea bellardii Ohba 1974

Порядок Kobresio-Dryadetalia (Br.-Bl. 1948) Ohba 1974

Союз?

Тип сообществ Dryas octopetala-Cladonia arbuscula

Установлено, что сообщества лишайниковых тундр исследованных ключевых участков характеризуются достаточно высокой видовой насыщенностью, разреженностью верхнего (травяного, травяно-кустарничкового или кустарничкового) яруса и господством лишайников в хорошо сформированном напочвенном покрове. Они произрастают на каменистом субстрате в суровых климатических и экологических условиях верхних поясов исследованных участков Уральских гор. Кроме того, проведенные исследования показали высокое разнообразие и частую встречаемость охраняемых в Республике Коми видов в этих типах сообществ, иногда - их участие в формировании фитоценозов в качестве ценозообразователей. Выявлено, что число редких таксонов, принадлежащих преимущественно к арктической фракции, выше на Приполярном Урале по сравнению с Северным. Это свидетельствует о хорошей сохранности растительного покрова природных экосистем лишайниковых тундр обследованной территории национального парка «Югыд ва».

Авторы признательны своим коллегам за обработку гербарных сборов споровых растений - Г.В. Железновой, С.Н. Плюснину, Т.Н. Пыстиной, за картографическе материалы - Л.Н. Рыбину, за помощь в сборе материала в полевых условиях - Е.Н. Патовой, И.В. Новаковской, за консультации при обработке материала - А.Б. Новаковскому.

Работа выполнена при финансовой поддержке бюджетного проекта АААА-А19-119011790022-1 и Госзадания Комплексной программы УрО РАН № 18-4-414.

\section{ЛИТЕРАТУРА}

Антропогенная динамика растительного покрова Арктики и Субарктики: принципы и методы изучения / ред. Б. А. Юрцев. - Труды Ботанического института им. В. Л. Комарова РАН. - Вып. 15. - 1995. $185 \mathrm{c}$.

Биоразнообразие водных и наземных экосистем бассейна реки Кожим (северная часть национального парка «Югыд ва» / В. В. Елсаков, А. А. Естафьев, Г. В. Железнова, И. В. Забоева, В. А. Канев, А. А. Колесникова, К. В. Куликова, Е. Е. Кулюгина, Е. М. Лаптева, О. А. Лоскутова, И. О. Марущак, Е. Н. Патова, С. Н. Плюснин, И. И. Полетаева, Н. П. Селиванова, М. Д. Сивков, А. С. Стенина, И. Н. Стерлягова, Л. Н. Тикушева, Е. И. Шубницина, В. М. Щанов. Сыктывкар, 2010. - 192 с.

Высотная дифференциация компонентов наземной биоты в горных тундрах Приполярного Урала (бассейн р. Балбанью) / Е. Е. Кулюгина, Е. Н. Патова, И. В. Новаковская, С. Н. Плюснин // Вестник Института биологии Коми НЦ УрО РАН. - 2015. - № 4 (192). C. 24-26.

Дёгтева, С. В. Растительность и флора природного парка «Югыд ва» (Республика Коми) / С. В. Дёгтева, В. А. Мартыненко // Ботанический журнал. - 2000. T. 85 , № 11 . - C. $76-86$.

Напочвенные лишайники / М. П. Журбенко, Л. А. Конорева // Растения и грибы полярных пустынь северного полушария / Н. В. Матвеева, Л. Л. Заноха, О. М. Афонина, А. Д. Потемкин, Е. Н. Патова, Д. А. Давыдов, В. М. Андреева, М. П. Журбенко, Л. А. Конорева, И. В. Змитрович, О. Н. Ежов, А. Г. Ширяев, И. Ю. Кирцидели. - Санкт-Петербург : МАРАФОН, 2015. - С. 133-166.

Игнатов, М. С. Список мхов восточной Европы и Северной Азии / М. С. Игнатов, О. М. Афонина, Е. А. Игнатова // Arctoa. - 2006. - T. 15. - C. 1-130.- DOI: 10.15298/arctoa.15.01

Изменения предгорных лесов бассейна реки Щугор по материалам спутниковой съемки периода 19862016 гг. / В. В. Елсаков, В. М. Щанов, В. С. Бирюкова, Е. Е. Кулюгина, Ю. А. Дубровский // Лесные экосистемы в условиях изменения климата: биологическая продуктивность и дистанционный мониторинг : Сборник научных статей [Электронный ресурс] / [редкол.: Э. А. Курбанов (отв. ред.) и др.] ; Поволжский гос. технологический ун-т. [и др.]. - Йошкар-Ола : Поволжский гос. технологический ун-т, 2016. - С. 5157.

Королева, Н. Е. Безлесные растительные сообщества побережья Восточного Мурмана (Кольский полуостров, Россия) / Н. Е. Королева // Растительность России. - 2006. - № 9. - С. 20-42.

Красная книга Республики Коми. - Сыктывкар. 2019. - 768 c.

Куваев, В. Б. Флора субарктических гор Евразии и высотное распределение ее видов / В. Б. Куваев. Москва : Товарищество научных изданий КМК, 2006. 568 с.

Кулюгина, Е. Е. Особенности состава и структуры сообществ с участием Acomastylis glacialis на границе ареала (Приполярный Урал) / Е. Е. Кулюгина // Теоретическая и прикладная экология. - 2018. - № 1. C. $73-79$.

Лавренко, А. Н. Флора Малдинского участка / А. Н. Лавренко // Влияние разработки россыпных месторождений Приполярного Урала на природную среду. Сыктывкар : Коми НЦ УрО РАН, 1994. - С. 41-66. 
Лавриненко, О. В. Зональная растительность равнинных восточноевропейских тундр / О. В. Лавриненко, И. А. Лавриненко // Растительность России. 2018. - № 32. - С. 35-108.

Лавриненко, О. В. Предварительные итоги классификации растительности восточноевропейских тундр и новый класс для зональных местообитаний / О. В. Лавриненко, Н. В. Матвеева, И. А. Лавриненко // Сборник научных трудов ГНБС. - 2016. - Т. 143. C. 95-105.

Лащенкова, А. Н. Эколого-географические закономерности в распределении растительности на Приполярном Урале / А. Н. Лащенкова, Н. И. Непомилуева // Экологические исследования природных ресурсов севера Нечерноземной зоны. - Сыктывкар : Коми филиал АН СССР, 1977. - С. 23-39.

Мартыненко, В. А. Естественное зарастание техногенных участков на Приполярном Урале / В. А. Мартыненко // Ботанический журнал. - 1986. - Т. 71, № 12 . - C. $1663-1668$.

Мартыненко, В. А. Конспект флоры национального парка «Югыд ва» (Республика Коми) / В. А. Мартыненко, С. В. Дёгтева. - Екатеринбург : УрО РАН, 2003. -108 c.

Мартыненко, В. А. Флора и растительность / В. А. Мартыненко, С. В. Дёгтева // Национальный парк «Югыд ва». - Москва : Дизайн. Информация. Картография, 2001. - С. 34-55.

Матвеева, Н. В. Растительность южной части острова Большевик (архипелаг Северная Земля) / Н. В. Матвеева // Растительность России. - 2006. - № 8. C. $3-87$.

Миркин, Б. М. Современная наука о растительности / Б. М. Миркин, Л. Г. Наумова, А. И. Соломещ. Москва : Логос, 2001. - 264 с.

Миркин, Б. М. Современное состояние основных концепций науки о растительности / Б. М. Миркин, Л. Г. Наумова. - Уфа, 2012. - 488 с.

Непомилуева, Н. И. Древесная растительность горных долин Приполярного Урала / Н. И. Непомилуева, В. В. Пахучий, Г. А. Симонов // География и природные ресурсы. - 1986. - № 4. - С. 72-80.

Непомилуева, Н. И. Редкие фитоценозы Приполярного Урала / Н. И. Непомилуева // Ботанический журнал. -1978 . - Т. 65, № 5. - С. 744-751.

Новаковская, И. В. Изменение разнообразия цианопрокариот и водорослей при зарастании пятен-медальонов горно-тундровых сообществ Северного Урала / И. В. Новаковская, Е. Н. Патова, Е. Е. Кулюгина // Ботанический журнал. - 2019. - Т. 104, № 4. C. 569-586. - DOI: 10.1134/S0006813619040057

Новаковский, А. Б. Взаимодействие Excel и статистического пакета $\mathrm{R}$ для обработки данных в экологии / А. Б. Новаковский // Вестник ИБ Коми НЦ УрО PAН. - 2016. - № 3. - С. 26-33.

Растительный покров и растительные ресурсы Полярного Урала / Л. М. Морозова, М. А. Магомедова, С. Н. Эктова, А. П. Дьяченко, М. С. Князев [и др.]. Екатеринбург : Изд-во Уральского университета, 2006. - 796 с.

Редкие растения окрестностей горы Хальмерсале (Северный Урал): эколого-фитоценотическая приуроченность, структура ценопопуляций, охрана / О. Е. Валуйских, Ю. А. Дубровский, Е. Е. Кулюгина, В. А. Канев // Вестник Томского государственного университета. Биология. - 2017. - № 40. - С. 66-87.
Синельникова, Н. В. Горные тундры юго-восточной части хребта Черского (Классы Loiseleurio-Vaccinietea Eggler ex Schubert 1960 и Carici rupestrisKobrisietea Ohba 1974) / Н. В. Синельникова // Растительность России. - 2013. - № 23. - С. 57-75.

Сравнительный анализ ценофлор горных тундр западного макросклона Северного и Приполярного Урала / С. В. Дёгтева, Е. Е. Кулюгина, Ю. А. Дубровский, А. Б. Новаковский // Теоретическая и прикладная экология. - 2014. - № 1. - С. 16-21.

Телятников, М. Ю. Обзор высших единиц высокогорной растительности Северной Евразии / М. Ю. Телятников // Сборник научных трудов ГНБС. - 2016. T. 143 . - С. $231-241$.

Телятников, М. Ю. Характеристика синтаксонов класса Loiseleurio-Vaccinietea северо-восточной части окрестностей оз. Пясино (юго-запад Северо-Сибирской равнины) / М. Ю. Телятников // Растительный мир Азиатской России. - 2010. - № 1 (5). - С. 33-41. DOI: $10.17223 / 19988591 / 40 / 6$

Флора и редкие виды горы Баркова / Е. Е. Кулюгина, Л. В. Тетерюк, Б. Ю. Тетерюк, И. А. Козлова // Современное состояние и перспективы развития сети ООПТ европейского Севера и Урала : материалы докладов Всероссийской научно-практической конференции» (Сыктывкар, Республика Коми, Россия, 23-27 ноября 2015 г.) / ред. С. В. Дёгтева, Л. Я. Огродовая, И. Н. Стерлягова. - Сыктывкар : ИБ Коми НЦ УрО PAH, 2015. - C. 208-215.

Флора сосудистых растений северной части национального парка «Югыд ва» // С. В. Дёгтева, В. А. Канев, Е. Е. Кулюгина, В. А. Мартыненко, И. А. Козлова, Ю. А. Дубровский, Б. Ю. Тетерюк, Л. В. Тетерюк, Л. Н. Тикушева // Известия Коми НЦ УрО РАН. - 2016. - № 4 (28). - С. 1-13.

Флоры, лихено- и микобиоты особо охраняемых ландшафтов бассейнов рек Косью и Большая Сыня (Приполярный Урал, национальный парк «Югыд ва»). Москва : Товарищество научных изданий КМК, 2016. $483 \mathrm{c.}$

Хвойные леса южной части национального парка «Югыд ва» (Республика Коми, бассейны рек Щугор и Подчерем) / Ю. А. Дубровский, Е. В. Жаангуров, В. В. Старцев, Н. А. Семёнова, Т. А. Сизоненко // Труды Карельского НЦ РАН. - 2019. - № 1. - С. 22-43. DOI: $10.17076 /$ bg883

Экотопическая приуроченность и состояние ценопопуляций редких видов растений в южной части национального парка «Югыд ва» (Северный Урал, Республика Коми) / О. Е. Валуйских, Е. Е. Кулюгина, В. А. Канев, Ю. А. Дубровский // Вестник Института биологии Коми НЦ УрО РАН. - 2017. - № 4 (202). C. 2-9. - DOI: $10.31140 /$ j.vestnikib.2017.4(202)3

Юдин, Ю. П. Горные тундры / Ю. П. Юдин // Производительные силы Коми АССР. Т. 3. Ч. І. Растительный мир. - Сыктывкар, 1954. - С. 277-322.

Юдин, Ю. П. Очерк растительности бассейнов рек Щугор и Подчерем (Северный Урал) / Ю. П. Юдин // Ботанический журнал. - 1950. - Т. 35, № 5. - С. 522526.

Lichenforming and lichenicolous fungi of Fennoscandia / R. Santesson, R. Moberg, A. Nordin, T. Tonsberg, O. Vitikainen // Museum of Evolution, Uppsala, 2004. 359 p. 


\title{
DIVERSITY OF LICHEN MOUNTAIN TUNDRA WITHIN THE WESTERN MACROSLOPE OF SUBPOLAR AND POLAR URALS
}

\author{
E.E. Kulugina, Y.A. Dubrovskiy \\ Institute of Biology of Komi Scientific Centre of the Ural Branch of the Russian Academy of Sciences, Syktyvkar
}

Summary. Tundra communities of lichen type prefer the most elevated of mountain landscapes and occur in the upper part of mountain-tundra altitudinal belt and the belt of mountain rocky deserts at the Subpolar and Polar Urals. Soils of lichen tundra are acid, low fertile and have relatively high temperature on the surface and inside the soil profile compared to other types of tundra. Tundra communities of lichen type form on the stony substrate, have scarce upper (herb, herb-dwarf shrub or shrub) vegetation layer. Soil surface is covered by lichens. The studies were conducted within the limits of the Yugyd va national park in its northern part at Subpolar Urals (Maldynyrd and Yuasnyrd Ridges, Barkova and Erkusey Mountains); and in its southern part at Northern Urals (Telpos-is Ridge). The aim of study was to reveal syntaxonomical diversity of lichen tundra communities. 50 releves were made at Subpolar Urals and 91 - at Northern Urals. We performed NMSordination by ExStaR software and found several clusters of releves, corresponding to syntaxa allocated within mountain tundra and mountain rocky deserts altitudinal belts. First ordination axis shows high correlation with the vector of elevation (r 0.83 at Subpolar and r 0.62 at Northern Urals). Within the mountain rocky deserts belt, three types of communities corresponding to the rank of association were found at Subpolar Urals: Carex arctisibirica-Cladonia stellaris; Carex arctisibirica-Novosieversia glacialis-Alectoria ochroleuca; Empetrum hermaphroditum-Arctagrostis latifolia-Alectoria ochroleuca. Three at Northern Urals: Carex arctisibirica-Flavocetraria nivalis; Carex arctisibirica-Cetraria islandica; Arctous alpinaAlectoria ochroleuca. Within the mountain tundra belt, two types of communities corresponding to the rank of association were found at Subpolar Urals: Empetrum hermaphroditum-Vaccinium vitis-idaea-Cladonia arbuscular and Empetrum hermaphroditum-Arctous alpina-Stereocaulon paschale. Four at Northern Urals: Salix nummularia-Racomitrium lanuginosum-Flavocetraria nivalis; Dryas octopetala-Cladonia arbuscula; Arctous alpina-Carex arctisibirica-Flavocetraria nivalis. One type of communities - Phyllodoce caerulea-Vaccinium myrtillus-Cetraria islandica are found both in the mountain tundra and the mountain rocky deserts belts with both geographical sectors of the Urals. So, 12 syntaxa of association rank were found in the tundra of lichen type at the study area. High number of rare and protected species (30 vascular plants 4 lichens and 1 moss) confirms the good preservation of the lichen tundra of the Yugyd va national park.

Key words: Lichen tundra, vegetation diversity, Subpolar and Northern Urals 